\title{
Concerning the Original Viewpoint of Biogeologic Accumulation of the Old Bedded Phosphorites in the Khubsugul and Zavkhan Basins of Mongolia
}

\author{
Dorj Dorjnamjaa, Gundsambuu Altanshagai \\ Institute of Paleontology and Geology, Mongolian Academy of Sciences, Ulaanbaatar, Mongolia \\ Email: ddorj2001@yahoo.com
}

Received 11 July 2015; accepted 26 September 2015; published 29 September 2015

Copyright (C) 2015 by authors and Scientific Research Publishing Inc.

This work is licensed under the Creative Commons Attribution International License (CC BY). http://creativecommons.org/licenses/by/4.0/

(c) (†) Open Access

\begin{abstract}
This paper concerns deals with biogeologic accumulation and their peculiarities, lithological unites of the phosphorite-bearing formations of these basins and an evolution of the old biota. Old bedded phosphorites are believed to be connected with specific biogeological events happening in the Neoproterozoic glaciation, which was followed by rapid deglaciation, Ediacaran bioradiation and the "great" postglacial transgression bearing phosphorites at its initial phase. The Mongolian phosphate basins give evidence of this phenomenon. Khubsugul basin is located in the northern Mongolia. The Neoproterozoic-Cambrian phosphorite-bearing khubsugul group is subdivided into $\mathbf{3}$ formations as ongolik, kheseen and erkhelnuur which are rich in organic fossils (a group of cyanobacterial mats, archaeocyaths, trilobites) in the ascending order. The Zavkhan basin lies in the western Mongolia. The Ediacaran-lower Cambrian sediments are divided into five formations: Maikhanuul (diamictites), Tsagaanolom (phosphorite-bearing carbonate), Bayangol, Salaanygol and Khairkhan. All the formations contain the paleontological fossils (algae, sponges, cyanobacterial mats, ichnocoenosis, soft-bodied fauna, archaeocyaths, etc.). Bedded phosphorites are the object for comprehensive research of bacterial paleontology. It is shown at example of the Mongolian Khubsugul and Zavkhan sea shelf phosphate basins. The expounded actual material clearly shows that the heterogeneous biologic activity, suitable geologic (transgressive systems tracts) and paleogeographic (glaciations, warm climate, etc.) conditions played an important role in the formation and accumulation of the biogenic bedded phosphorites.
\end{abstract}

\section{Keywords}

Khubsugul, Zavkhan, Basin, Phosphorite, Fossils, Biota, Accumulation

How to cite this paper: Dorjnamjaa, D. and Altanshagai, G. (2015) Concerning the Original Viewpoint of Biogeologic Accumulation of the Old Bedded Phosphorites in the Khubsugul and Zavkhan Basins of Mongolia. Open Journal of Geology, 5, 666-675. http://dx.doi.org/10.4236/ojg.2015.59059 


\section{Introduction}

During the late Precambrian-Early Cambrian period important increases took place in the oxygen concentration of the atmosphere and hydrosphere, the unicellular eucaryotes, procaryotes diversified, stromatolites, microphytolites, and metazoa more appeared. The formation of supercontinents assisted the development of glaciations. The many new passive continental margins and oceans and consequent upwelling of nutrient-rich currents enabled global deposition of phosphorites and rapid development of biota with hard parts. The first major period of phosphate accumulation was in the Neoproterozoic-Lower Cambrian, contemporaneous with the fast development of shelly faunas [1]. Phosphorite genesis correlates with elevated sea-level resulting from transgression, allowing deposition on shallow shelves, and with warm climate which may be related to an increased phosphorus flux to the oceans during times of increased chemical weathering on land, and to the development of widespread oxygen-depleted waters because rates of oceanic circulation and oxygen solubility are reduced [2]. According to A.V. Ilyin [3], Latest Precambrian-Early Cambrian phosphate basins in Asia occurred on continental margins of old Precambrian continents. Broad oceanic areas are reconstructed between old continents. They embraced deep water basin, marginal seas, island volcanic arcs, etc. Carbonate sediments are revealed on continental margins. They are lithologically persistent, rather thick and envelop broad age interval, i.e. from Ediacaran to Middle Cambrian in Zavkhan basin and Upper Cambrian in Khubsugul basin. Carbonate sediments were most probably accumulated on shelfes. They are usually found as host rock for phosphorite beds. Neoproterozoic-Cambrian continents were formed as a result of Latest Precambrian rifting of Protopangea and a spreading that followed.

\section{The Precambrian-Cambrian Boundary}

The start of the Neoproterozoic was anew placed at 1000.0 Ma and the base of the Cambrian at $542 \pm 1.0 \mathrm{Ma}$. The position of the Precambrian-Cambrian boundary is relevant to the Ediacaran fauna of soft-bodied organisms which developed in latest Precambrian time. The late Precambrian metazoan assemblage contains at least 26 species in 18 genera and 4 or more phyla, and includes many species that are known today such as jelly-fish, sea anemones, the sea wasp (Insecta: braconid and scelionid wasps), serpulid worms, sponges, sea pens, as well as several types of creatures unlike any known organisms. Many of the fossils are generally interpreted as coelenterates, and some as arthropods, annelids or other triploblasts [4]. The Ediacaran fauna has a worldwide distribution with important localities in Russia (White Sea and N. Siberia), Australia, Canada (Mackenzie and Wernecke Mountains of NW Canada and SE Newfoundland respectively), Namibia, England (Charnwood, Leicestershire), China, and Mongolia. The Neoproterozoic-Cambrian radiation events can be interpreted in terms of three main processes: 1) Biological (evolutionary diversification into vacant niches and evolutionary responses to preparation and croppin pressures); 2) Environmental (new groups evolving in response to major transgressions, deglaciations, nutrient supply and access to extensive shallow marine habitats); 3) Geochemical (evolution of groups forced through changes in atmosphere-hydrosphere chemistry, particularly $\mathrm{pCO}_{2}$ and phosphate levels). By M. E. Tucker [5] and D. Dorjnamjaa et al. [6], the radiation comprised five episodes or stages of development: 1) Prevendian (Pretonian)-unicellular procaryotes and eucaryotes; 2) Mid-late Vendian (TonianGryogenian) fauna, early trace fossils, and acritarchs; 3) Nemakit-Daldynian (late Vendian or Ediacaran)-phosphatic small shelly fossils, many shallow-water trace fossils, and calcified cyanobacteria; 4) Tommotian (basal Cambrian)-calcareous small shelly fossils with the first archaeocyathans, molluscus and medusoid; 5) Atdabanian-abundant archaeocyathans with trilobites, brachiopods, echinoderms and deeper water trace fossils. All these episodes took place at a time when a supercontinent was breaking up, leading to the formation of the Iapetus ocean. A major factor in all the changes going on at the Precambrian-Cambrian boundary was the chemical change within the oceans, and this was related to two aspects, global climate, i.e. the change from Neoproterozoic (Sturtian) icehouse (glaciations) to Cambrian greenhouse, and global tectonics, i.e. the opening of few oceans and seaways [2]. Nevertheless during these monumental changes some species did survive. Although the significant event during the "Cambrian biological explosion” was rapid development of organisms with exoskeletons and biomineralization [7], some soft-bodied Neoproterozoic faunas did survive, because they are preserved in the incredible Burgess Shale-type faunas that are known from nearly 40 Lower and Middle Cambrian localities in the world [8]. In this way, the Precambrian-Cambrian boundary was the end of the beginning and the beginning of the end in the biogeological event. Bacteria are the beginning of life. Phosphorite sediments in the Khubsugul and Zavkhan bassins are realizable fact for an explanation of this phenomenon. 


\section{Interpretation and Discussion}

\subsection{Khubsugul Phosphate Basin}

The Khubsugul phosphate basin is located on the Tuva-Mongolian microcontinent, which was carbonate platform in the Ediacaran-Cambrian period (Figure 1). The biostratigraphycal study of phosphorite has greatly expanded over the past forty odd, and more years. In the 1970's-1990's there existed a need for the recognition of spatial and temporal relationships of the explosive appearance of hard skeleton of organisms on the beginning of the Cambrian ([9] [10] and many others) as well as the contemporary formation of the largest deposits of phosphorite in China, Mongolia, and Kazakhstan.

N. A. Donov and E. V. Edemsky discovered the first phosphorite deposit in Mongolia in 1963 on the western coast of the Khubsugul Lake. This discovery was followed in 1964-1967 by detailed investigations of the AllUnion Air-Geological Trust and NILZarubezhgeologia institute. Besides the pioneer investigators, $\mathrm{M}$. M. Muzylevsky, A.A. El' yanov and A. V. Ilyin took part in this work. A. V. Ilyin collectively with A. L. Yanshin and

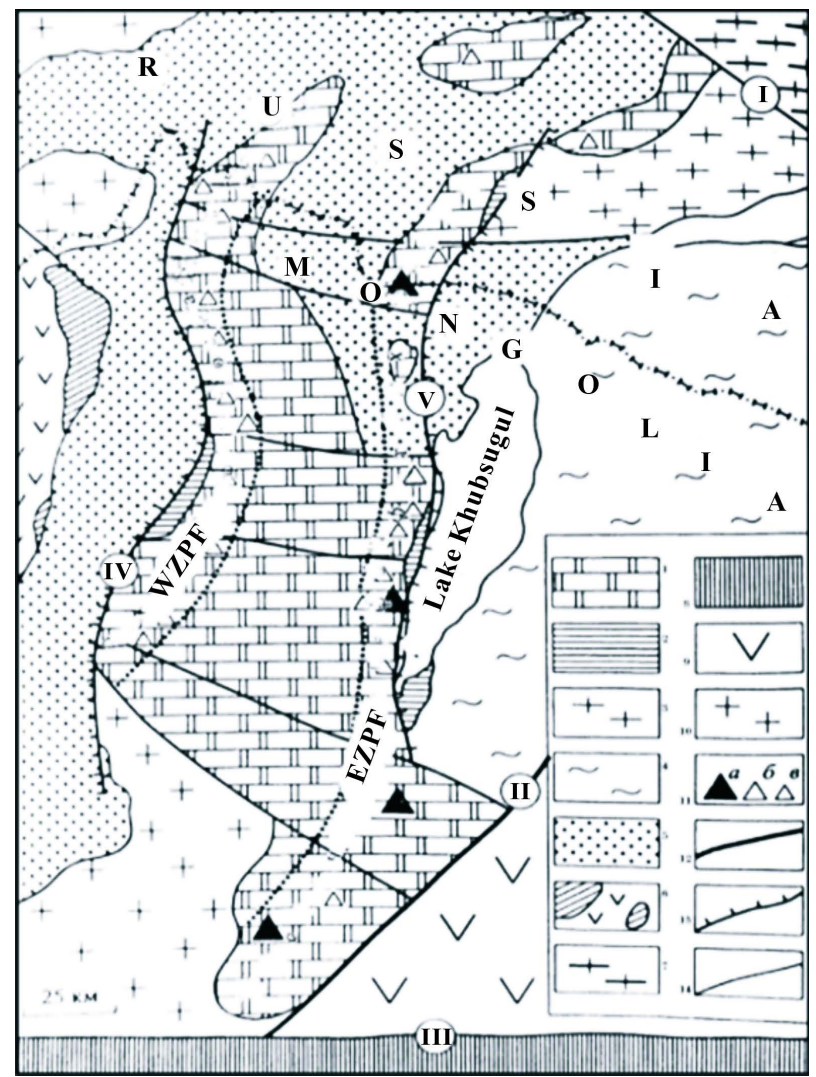

Figure 1. Geological scheme of the Khubsugul phosphate basin and surrounding area. 1, 2-NeoproterozoicCambrian sediments: 1-khubsugul group: ongolik, kheseen (phosphorite-bearing) and erkhelnuur formationssandstone, gravelstone, limestone, dolomite, phosphorite, 2-darkhat group (arasan formation)-arkose, sandstone, rhyolite, basalt, pelitomorphic dolomite; 3-6-Ancient complex of basement: 3-granulite of Gargan balance block (paleoproterozoic), 4-gneiss, crystalline schist, amphibolite and marble of Khamardavaa and Urigol upstanding block (paleoproterozoic-mesoproterozoic), 5-green schist, limestone, graywacke, andesite-dacitic volcanite of Khug formation (mesoproterozoic), 6-ophiolite of Shishkhid arc (neoproterozoic); 7-9-Framing of Tuva-Mongolian massif: 7-Siberian craton, 8-central Mongolian micro continent (pre-Neoproterozoic), 9-Jid oceanic zone (neoproterozoic-cambrian); 10-Early Paleozoic granitoid; 11-Phosphorite deposits and phosphate occurrences: a, b-large deposits; (a-explored, b-unexplored), b-phosphate occurrences; 12-Suture (accretionary) zone: I-Big Sayan fault, II-Argyingol fault, III-Khangay-Khentey fault (the earthquake suture of 1905); 13-Marginal thrust framing khubsugul basin: IV-Khugiingol, V-coastal; 14-Ancient fault in basement determinative block structure of basin. WZPF-western zone of phosphatic facies, EZPEeastern zone of phosphatic facies (based on the map compiled by A.V. Ilyin [3] and D. Dorjnamjaa et al. [11]). 
N. S. Zaitsev revealed that the Khubsugul basin is among the largest phosphate basins of the world. From 1968 to the present, the Khubsugul phosphate basin was studied by collaborators of the Geological and Paleontological institutes (Russian Academy of Sciences), as well as the Joint Russian-Mongolian Geological and Paleontological expeditions ([10]-[13], etc.). As was shown in Figure 2, the Neoproterozoic (Tonian-Cryogenian and Ediacaran)-Cambrian sediments are divided in two groups-lower (Darkhat) and the upper (Khubsugul). Within the Arasan and Kheseen rivers (Khubsugul phosphorite deposit) the Darkhat group is represented by its uppermost Arasan formation $(1500 \mathrm{~m})$ which consists predominantly of siliciclastics and volcanics-siliciclastics, namely green, gray, brown, or rare violet siltstone, sandstone, tuffaceous sandstone, and gravestone with some

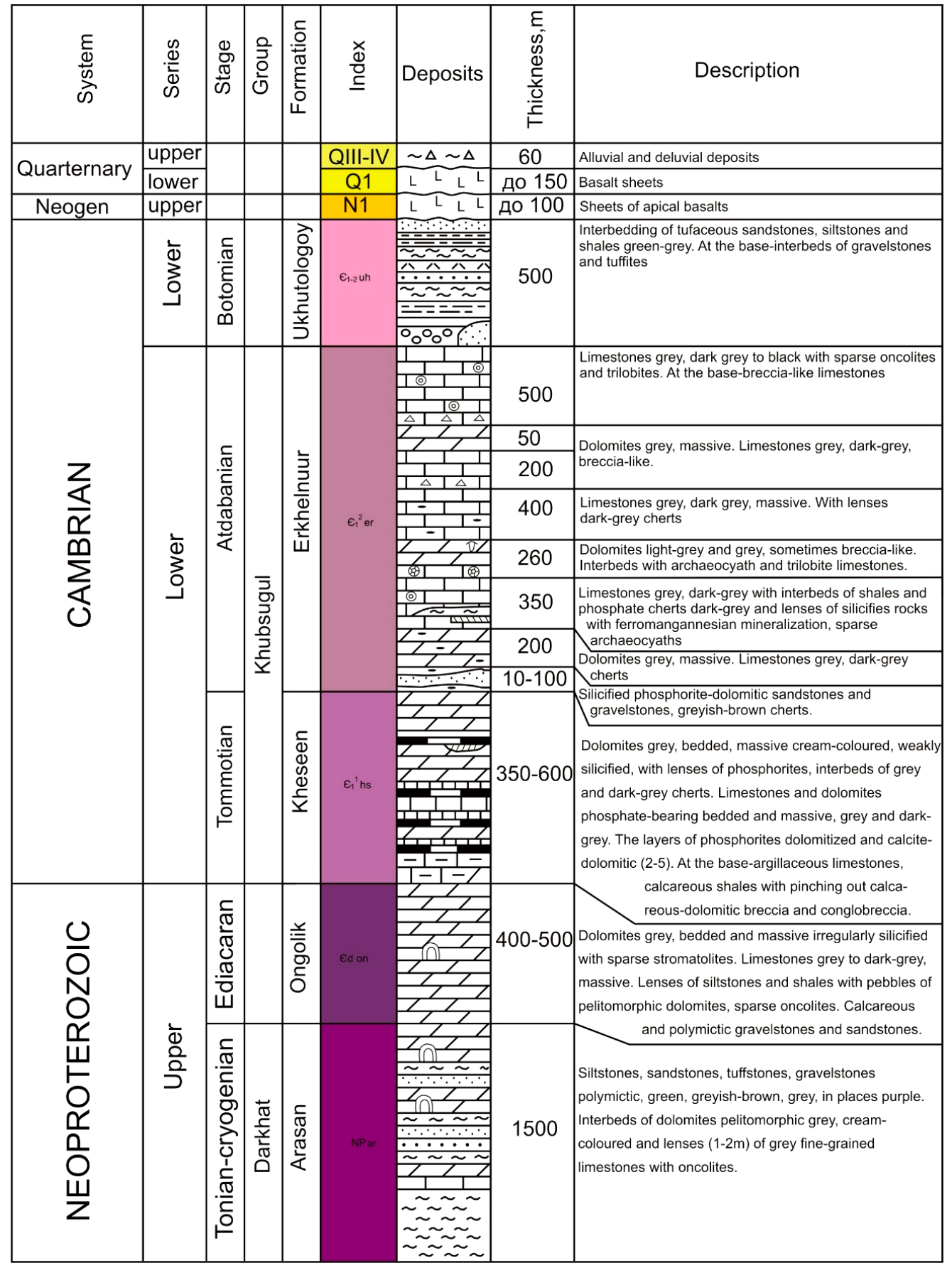

Figure 2. Stratigraphic column of the Khubsugul basin 
layers of grayish-cream pelitomorphic dolomite and lenses (1 - $2 \mathrm{~m})$ of gray thin-grained limestone with oncolites (microphytolites). The Khubsugul group lies unconformably on the Arasan formation and is subdivided into three formations in the ascending order, Ongolik, phosphorite-bearing Kheseen, and Erkhelnuur formations [10]. The Ongolik formation $(400-500 \mathrm{~m})$ overlies the Arasan formation with a washout and basal quartz-feldspathic sandstone and gravelstone of about $2-15 \mathrm{~m}$ in thickness. They pass upward to gray bedded and massive dolostone, silicified in places, with rare microphytolites and algamorphic texture. The uppermost part of the Ongolik formation consists of conglomerate-breccia slump features and erosional surface. From the dolostone we have been able to reveal medusoid fossils and microphytolites. These fossils indicate the upper Vendian or Ediacaran age [6] [10] [11] [14]-[17]. The Kheseen formation overlying the Ongolik formation is subdivided into three members. The lower member consists of argillaceous limestones and calcareous shales with lenses of calcareous-dolomitic breccia and conglomerate-breccia. The middle member is the principal productive horizon of the formation and contains several phosphorite layers of the Khubsugul basin. Carbonate bedded phosphorites builds the main horizon, $10 \mathrm{~m}$ thick with average $22 \% \mathrm{P}_{2} \mathrm{O}_{5}$. The upper portion of the unit contains rich small-grained phosphorites, with $28 \%-34 \% \mathrm{P}_{2} \mathrm{O}_{5}$. The phosphorite layers alternate with bedded and massive limestone and dolostone, in places with siliceous-aleuritic-argillaceous shale, and black chert. They are from one to five phosphorite horizons in the different parts of the member, which compose up to $10 \%-15 \%$ of its thickness. The upper member begins with black amorphous chert of thickness from several meters to $50 \mathrm{~m}$, overlian by dolostone and limestone with a significant admixture of argillaceous and arenaceous particles. The total thickness of the Khesen formation varies from 350 to $600 \mathrm{~m}$. Russian paleontologists [10] first time did discovery a group of cyanobacterial mats (Khubsugul biota) from the middle part of the phosphorite member (Figure 3). The Khubsugul biota was probably mostly cyanobacterial: Archaeooides sp., A. granulatus Qian, Tasmanites tennelus Volkova, Obruchevella sp., Spirellus sp., and filamentous, belonging to genera, known from older rocks, namely, Siphonophycus robustum (Schopf), S. typicum (Hermann) Butterfield, S. solidum (Golub) Butterfield, S. septatum (Schopf), Oscillatoriopsis obtusa Schopf. The forms listed above mostly span both the Neoproterozoic and Lower Cambrian, but Archaeooides, Tasmanites, Osagia senta, and several catagraphia (Nubecularites) appear from the Lower Cambrian Tommotian stage only [10]. The overlying Erkhelnuur formation (2060 m) contains Atdabanian trilobites. Along the Khesen and Ongolik rivers M. N. Korobov [13] in the presence of D. Dorjnamjaa in 1974 found two levels with trilobites. The lower one is 400 - $550 \mathrm{~m}$ above the base of the formation and contains Archaeaspis sp., Malykania ongolica Korob., Elganellus delatatus Korob., E. pensus Suv., E. elegans Suv., E. probus Suv., E. elongatus E. Rom., Resserops kharganicus Korob., Pseudoresserops obesus Korob., Minusella priva Korob. The upper level is $250 \mathrm{~m}$ above the lower one, spans about $250 \mathrm{~m}$ and contains Bulaiaspis teseevica Rep., Fallotaspidella chesenica Korob., and Fallotaspis mongolicus Korob. At the Burenkhaan deposit area, the upper Erkhelnuur formation contains numerous Botomian archaeocyathids: Palaeoconularia baileyi (Vol.), Sibirecyathus naletovi Vol., Formosocyathus vermiculatus (Vol.), Tubericyathus clathratus Vol., Clathricoscinus

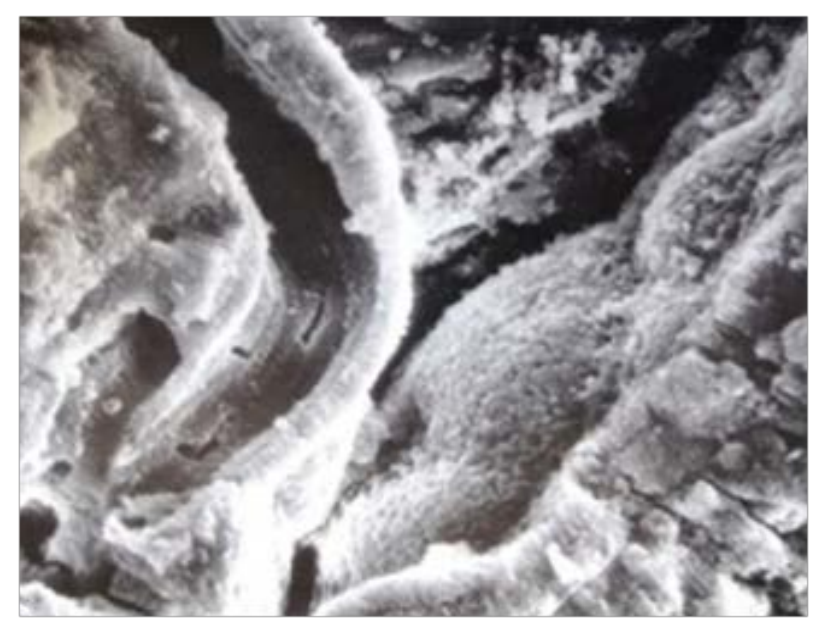

Figure 3. Type of preservation of cyanobacterial filaments and purple bacteria. Kheseen formation, Khubsugul basin [10]. SEM photomicrographs of the phosphatized microorganisms from the Cambrian Khubsugul phosphorites that exhibit similar form and size to the recent cyanobacterial mat microorganisms. 
vassilievi (Vol.), C. dentatus (Vol.), Claruscoscinus billingsi (Vol.), Archaeocyathus operosus (Zhur.), (A. Yu. Zhuravlev's data). The tuffaceous-siliciclastic Ukhutologoy formation (500 m thick) overlies the Erkhelnuur formation with a break. At the southern border of the Khubsugul Lake, this formation contains trilobites and archaeocyathids: Irinaecyathus ex. gr. ratus (Vol.) and Pycnoidocyathus sp., which are of the Botomian age. Thus, the phosphorite-bearing Kheseen formation is considered to be as Tommotian Lower Cambrian age.

\subsection{Zavkhan Phosphate Basin}

D. Dorjnamjaa and L. Ochir discovered first phosphorite deposit (Alagiin Davaa) in the Zavkhan basin in 1983 within the western Mongolia [16]. This phosphate basin extends toward the western edge of Mongolia in GoviAltay and Zavkhan area and forms a broad structural-tectonic zone of Neoproterozoic and Early Paleozoic sediments [6] [11] [14] [16] [18]-[20]. On the whole, the Neoproterozoic to Cambrian stratigraphy of the Zavkhan basin was first described by V.V. Bezzubtsev [21] in the Bayangol Gorge area. It was further studied by Russian and Mongolian geologists and paleontologists between 1978-2014 and researchers participating in the IGCP Project 303, "Precambrian-Cambrian Event Stratigraphy", in 1993 [9] [19] [22]-[24]. According to these investigations the Neoproterozoic and Lower Cambrian strata of the Zavkhan basin are divided into six formations: the Zavkhan (3000 m), Maikhanuul (220 m), Tsagaanolom (1900 m), Bayangol (720 - $1000 \mathrm{~m}$ ), Salaanygol (600 $\mathrm{m})$, and Khairkhan (380 m) formations (Figure 4). The Zavkhan formation (732 - $777 \mathrm{Ma}$, [16]) is represented by basaltic andesite and andesites in the lower and by felsic volcanics in the upper part of the section, with numerous explosive units, such as pyroclastic tuffs and ignimbrites and toward the top, arkosic and quartzose sandstones appear. The Maikhanuul formation which rests uncomfortably upon the Zavkhan volcanic sequence consists of glaciogenic and other clastic deposits and comprises two relatively thin units of diamictites separated by a section of flysch sediments. The Maikhanuul tillites are overlain by massive carbonate units of the Ediacaran (Nemakit-Daldynian) Tsagaanolom formation [25]. In turn, the early Cambrian clastic sediments of the Bayangol and other above deposited formations rest conformably upon the limestones of the Tsagaanolom formation. The rocks of the lower and upper units of the Maikhanuul formation contain highly angular boulders, bed penetrating dropstones, striated clasts that show evidence of glacial activity. The key sections of the phosphorite-bearing Tsagaanolom formation were studied by us within the Alagiin Davaa and Tsakhir Uul deposits, also in the Zuun-Baruun Arts, Bayangol, Salaanygol and Khevtee Tsakhir area. On the whole in lithology and geochemistry, the Tsagaanolom formation is distinctly subdivided into underphosphoritic (dolomitic), phosphoritic and overphosphoritic members. The phosphoritic member itself is subdivided in the same way. Within the underphosphorite part of the section there are two remarkable intervals. The lower interval (with the exception for basal layers) shows monotonous alternation of dark and light indistinct finely grained pelagic dolomites with separate rare members and layers with signs of shallower conditions-stromatolitic and microphitolitic crosslayered carbonates, slide breccias, silicified horizons. This lower interval $(500-700 \mathrm{~m})$ reflects the initial stage of pulsation transgression. The phosphoritic member $(70-80 \mathrm{~m})$ above the "lower" dolomite is essentially siliceous and terrigenous. It consists of 2 or 3 phosphate horizons $0.2 \%-0.5 \%$ to $6 \%-7 \%$ to $20 \%-26 \%$, not infrequently may get through to $30 \%-35 \%$. The phosphoritic horizon is often a single layer whose thickness, e.g., in the Tsakhir Uul (deposit) and Khevtee Tsakhir (occurrence), reaches up to $40 \mathrm{~m}$. Usually it is less, only a few meters on the erosional surfaces. Just this horizon marks the beginning of a phosphorite member, there is an erosion surface in its bottom. Precisely this marker horizon is very characteristic for the whole Zavkhan phosphate basin. The over phosphoritic member ( 1000 - $1100 \mathrm{~m})$ begins with black shales $(1-3 \mathrm{~m})$, which contain no more sand-aleurolite impurity. Above follows the alternation of wave-bedded and thin-layer black and yellowish (argillaceous) limestones, calcareous dolomites, sometimes with cross-bedding and intraclasts (small plane carbonate pebble) or calcarenites (20 - 30 m). The lower layers contain plane-wave stromatolitic textures [16], trace fossils, lenses of derived phosphate. Above lie, chiefly, black limestones with plane-rounded, spheroidal and semispherical algal bioherms, calcarenites. Having calcareous nature, deep-black color, algal textures, trace fossils, wavy and cross-bedding, abundance of relatively large intraclasts, the overphosphoritic section differs from the pure dolomite underphosphoritic part, which is gray and more evently bedded, with small intraclasts (expect for horizons of block-megaclastic slide breccias). This postphosphate stage (3rd part) proceeded as a new phase of transgression but already on the background of an essentially planed relief of the bottom of the regressed basin. It began with deposition of clay material in lagoons, later giving way to carbonates. The carbonate and carbonate-terrigenous sediments of the Tsagaanolom, Bayangol, Salaanygol, and Khairkhan formations, which are 


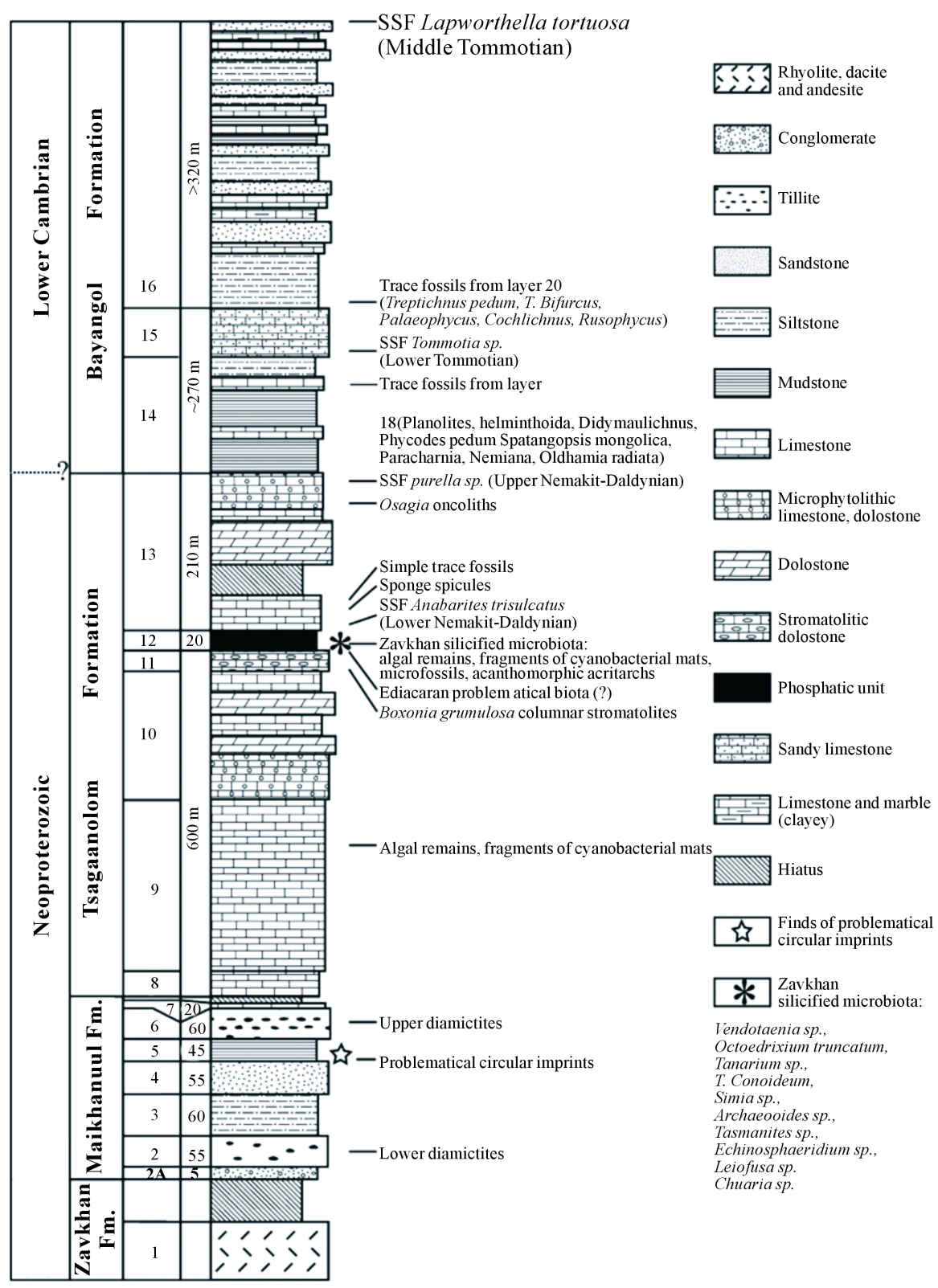

Figure 4. Geological succession of the Neoproterozoic-Lower Cambrian sediments in the Zavkhan basin; distribution of organic remains and trace fossils in the Tsagaan Gol and Bayan Gol sections (Zavkhan microbiota). Modified after Khomentovsky and Gibsher [19] and Serezhnikova et al. [25].

compiled the Zavkhan shelf basin have abundant shallow faunal and floristic fossils. We must emphasize that for last 15 years we have conducted new research on bacterial paleontology combined with old bedded phosphorites in the both Zavkhan and Khubsugul basins. As a result of this investigation were discovered by us the unexpected new finds (Zavkhan microbiota) of the cyanobacterial mats (Octoedrixium truncatum, Tanarium sp., Simia sp., Archaeooides sp., Tasmanites sp., etc.) in bedded phosphorites of the Khesen and Tsagaanolom formations [2] [17]. The phosphate-aluminous-bearing Bayangol formation has abundant assemblages of trace fossils which are confirmed by R. Goldring and S. Jensen [26]. It should be emphasized that we have discovered a stony or black metaphosphorite occurrence with high content of $\mathrm{Al}_{2} \mathrm{O}_{3}$ (up to $15 \%$ - 33\%) in the Bayangol formation close to the Alagiin Davaa deposit (Khundlun Uul area) of the Zavkhan phosphate basin [16]. This distinctive metaphosphorite of Khundlunuul type also has been revealed by us within the Alag Uul mountain in the 
south-west of Alagiin Davaa deposit. The common reserve of this deposit was estimated as 80 million tonne of the phosphorite ore in the presence of average content $\mathrm{P}_{2} \mathrm{O}_{5} 18 \%$. In the lower part of the Bayangol formation were revealed Didymaulichnus miettensis, Helminthoida cf. miocenica, Planolites isp. and Phycodes pedum Seilacher together with the psammocorals Spatangopsis mongolica Dorjnamjaa and Nemiana. In the upper part contains a more diverse assemblage including Phycodes pedum, Helminthoida cf. miocenica, Palaeophycus tubularis, Rusophycus cf. avalonensis, Monomorphichnus isp., Treptichnus bifurcus, T. cf. triplex., Cochlichnus isp., Hormosiroidea isp., Planolites isp., Didymaulichnus miettensis (Figure 5). Moreover, in 1988 year from lower Cambrian section close to Taishir sum (province) we have revealed trace fossils (imprint) of genus Paracharnia Sun, 1986, which first was known in China at the base of the Dengying formation (Shibantom member) and Ichnogenus Oldhamia radiata Forbes, 1848 (or medusoids [11] [16]). At the same time it is well known the calcimicrobial bioherms and biostromes of inferred Ediacaran-Nemakit-Daldynian and Tommotian age, which are widespread in the Zavkhan basin. They are constructed by Renalcis, Korilophyton, Tarthinia and Botominella, among other forms. Nemakit-Daldynian bioherms were domal to stacked-columnar at least, while by Tommotian time domal, bulbous, prolate or columnar-oblate examples are known. Late Atdabanian-early Botomian calcimicrobial crusts, calcimicrobial bioherms and radiocyathan-archaeocyathan bioherms are recognized in the Salaanygol formation at Salaany Gol. Overall, the archaeocyathan assemblage of the Salaanygol formation

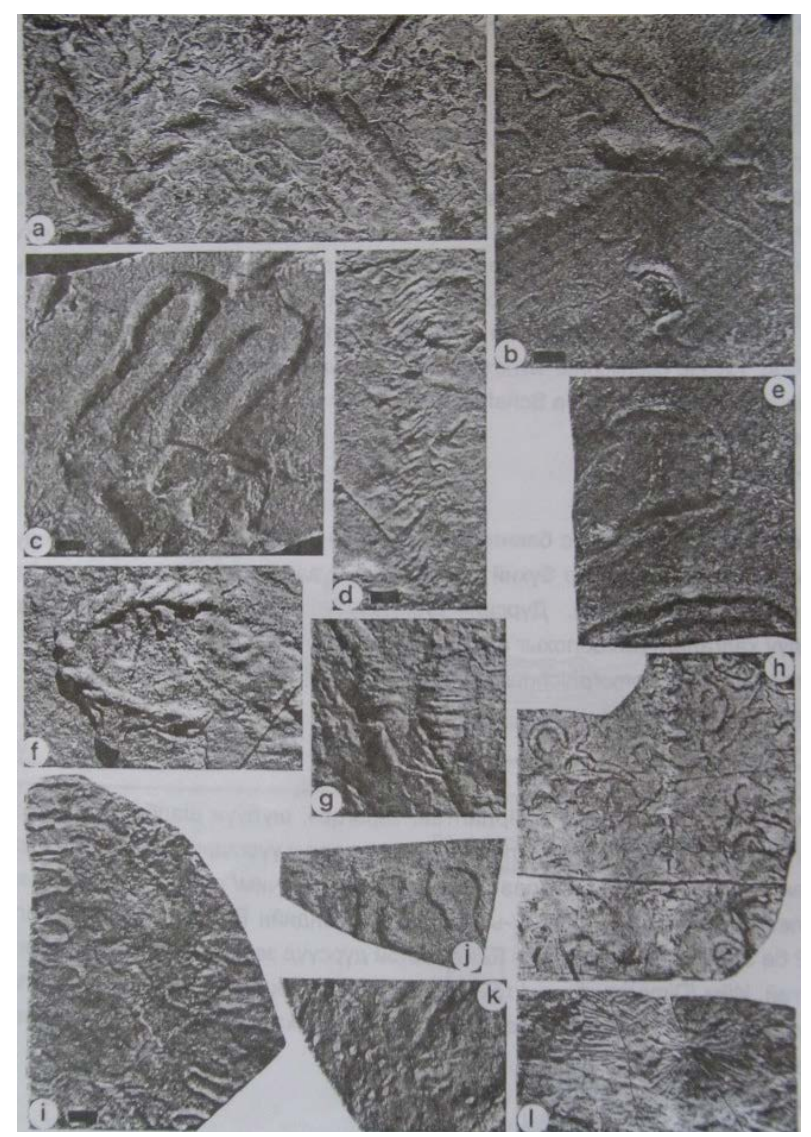

Figure 5. (a) (f) Phycodespedum seilacher: (a) negative epirelief, (f) positive hyporelief. (b) Cochlichnus isp. Probably lower surface expression; lower example evently sinuous, upper irregularly sinuous. (c) (h)-(j) Helminthoida cf. miocenica Sacco. Probably positive hypichnia (I, OUM AY 16). (d) Monomorphichnus isp. Lowersurface expression. (e) Helminthoida isp. probably a hypichnion (OUM AY 12). (g) Rusophycus cf. avalonensis Crimes \& Anderson, positive hyporelief. (k) Hormosiroidea isp. hypichnial expression, (OUM AY9). (1) Oldhamiaradiata forbes (OUM AY10). All specimens are from unit 20, Bayan Gol section expect those illustrated (h) which is from unit 18, and (e) and (i) which are from Taishir I. Scales: (a)-(d), (i): $\times 0.7$; others $\times 1.0$. Specimens figured (a)-(d) (f) (g) (j) are deposited at the Scientific museum of Paleontological and Geological Institute of the MAS [15] [16] [26]. 
shows a clear species-commonality with Siberian faunas. It is typified by simply organized archaeocyaths: Archaeolynthus, Dokidocyathus, Nochoroicyathus and Rotundocyathus, with simple outer and/or inner walls, are most abundant among the regular archaeocyaths. The deposition of the Salaanygol formation under reasonably high-energy conditions is supported by associated lithological features such as well-developed marine cements and more or less abundant grainstones and packstones. The late Atdabanian-early Botomian Zavkhan basin bioconsructions can be compared with those of the same age range in neighbouring Siberia and Gondwana.

\section{Results}

The biogenic phosphorites are the concrete evidence and object for an academic research of bacterial paleontology. Actually bacteria were a beginning of any life. The "Khubsugul" and "Zavkhan" biota was mostly cyanobacterial. The cyanobacterial mat community was preserved in the phosphorites as stromatolites, microphytolites, blue-green algal remains and micronoduls side by side with trace and small shelly fossils, also spiculate sponges. The micronodules are clearly predominant in our observations. The micronodule sizes usually vary from tens to several hundreds of microns (Archaeooides, Tasmanites).

\section{Conclusion}

The expounded actual material clearly shows that the heterogeneous biologic activity, suitable geologic (transgressive systems tracts) and paleogeographic (glaciations, warm climate, etc.) conditions played an important role in the formation and accumulation of the biogenic bedded phosphorites. Preservation of organic remains is dependent upon the nature of the material to be preserved and the depositional environment in which it accumulates. Fossil occurrences are thus facies dependent.

\section{Acknowledgements}

We thank colleagues at the Geological Institute (GI, RAS, Moscow), N. S. Zaitsev, at the Paleontological Institute (PIN, RAS, Moscow), A. L. Ragozina, E. A. Serezhnikova, and M. D. Brasier, Rachel Wood (Cambridge) for field support and joint research, Academician A. L. Yanshin, A. Yu. Rozanov (Moscow, Russia) and R. Barsbold (Ulaanbaatar, Mongolia) are thanked for help in many-sided arranging the field expeditions in Mongolia.

\section{References}

[1] Cook, P.J. and Shergold, J.H. (1984) Phosphorus, Phosphorite and Skeletal Evolution at the Precambrian-Cambrian Boundary. Nature, 308, 231-236. http://dx.doi.org/10.1038/308231a0

[2] Windley, B.F. (1995) The Evolving Continents. 3rd Edition, John Wiley and Sons, Hoboken, 526.

[3] Ilyin, A.V. (2008) Old (Ediacaran) Phosphorites. GEOS, Moscow, 160. (In Russian)

[4] Conway Morris, S.J. (1992) Burgess Shale-Type Faunas in the Context of Cambrian Explosion: A Review. Journal of the Geological Society (London), 149, 631-636. http://dx.doi.org/10.1144/gsjgs.149.4.0631

[5] Tucker, M.E. (1992) The Precambrian-Cambrian Boundary: Seawater Chemistry, Ocean Circulation and Nutrient Supply in Metazoan Evolution, Extinction and Biomineralization. Journal of the Geological Society (London), 149, 655-668. http://dx.doi.org/10.1144/gsigs.149.4.0655

[6] Dorjnamjaa, D., Enkhbaatar, B. and Altanshagai, G. (2015) Concerning Precambrian and Cambrian Regional Stratigraphy of Mongolia. Ulaanbaatar, Mongolian Geoscientist, 42, 2-11.

[7] Runnegar, B. and Bengtson, S. (1990) Origin of Hard Parts-Early Skeletal Fossils. In: Briggs, D.E.G. and Crowther, P.R., Eds., Palaeobiology: A Synthesis, Blackwell Scientific Publications, Oxford, 24-29.

[8] Conway Morris, S.J. (1992) Burgess Shale-Type Faunas in the Context of Cambrian Explosion: A Review. Journal of the Geological Society (London), 149, 631-636. http://dx.doi.org/10.1144/gsjgs.149.4.0631

[9] Lindsay, J.F., Brasier, M.D., Dorjnamjaa, D., Goldring, R., Kruse, P.D. and Wood, R.A. (1996) Facies and Sequence Controls on the Appearance of the Cambrian Biota in Southwestern Mongolia: Implications for the Precamrian-Cambrian Boundary. Geological Magazine, 133, 417-428. http://dx.doi.org/10.1017/S0016756800007585

[10] Zhegallo, E.A., Rozanov, A.Yu., Ushatinskaya, G.T., Hoover, R.B., Gerasimenko, L.M. and Ragozina, A.L. (2000) Atlas of Microorganisms from Ancient Phosphorites of Khubsugul (Mongolia). Huntsville, Alabama, 167.

[11] Dorjnamjaa, D. and Bat-Ireedui, Y. (1991) The Precambrian of Mongolia. Nauka, Ulaanbaatar, 182. (In Russian) 
[12] Ilyin, A.V. (1973) Khubsugul Phosphate Basin. Nauka, Moscow, 161. (In Russian)

[13] Korobov, M.N. (1980) Biostratigraphy and Miomeric Trilobites of the Lower Cambrian of Mongolia. In: Menner, B.B. and Mein, S.V., Eds., Lower Cambrian and Carboniferous Biostratigraph of Mongolia, Vol. 26, Nauka, Moscow, 5105. (In Russian)

[14] Dorjnamjaa, D., Enkhbaatar, B. and Altanshagai, G. (2014) Precambrian and Cambrian Regional Stratigraphy of Mongolia. In: Rocha, R., Pais, J., Kullberg, J.C. and Finney, S., Eds., STRATI 2013: First International Conference on Stratigraphy at the Cutting Edge of Stratigraphy, Springer International Publishing, Switzerland, 391-395. http://dx.doi.org/10.1007/978-3-319-04364-7_76

[15] Dorjnamjaa, D. and Enkhbaatar, B. (2012) Precambrian and Cambrian Paleontology of Mongolia. In: Barsbold, R., Ed., Paleontology, Vol. II, Soyombo Printing, Ulaanbaatar, 14-31, 167-181. (In Mongolian)

[16] Dorjnamjaa, D. and Soyolmaa, D. (2001) Zavkhanphosphate Basin. Interpress, Ulaanbaatar, 166. (In Mongolian)

[17] Ragozina, A.L., Dorjnamjaa, D., Krayushkin, A.V., Serezhnikova, E.A. and Enkhbaatar, B. (2010) Vendian-Cambrian Biota of the Western Mongolia. In: Podobina, V.M., Ed., Evolution of Life on the Earth, Proceedings of the IV International Symposium, TML-Press, Tomsk, 187-190.

[18] Dorjnamjaa, D., Byamba, J. and Enkhbaatar, B. (2012) Precambrian and Cambrian Stratigraphy of Mongolia. In: Byamba, J., Ed., Stratigraphy, Vol. I, Soyombo Printing, Ulaanbaatar, 54-160. (In Mongolian)

[19] Khomentovsky, V.V. and Gibsher, A.S. (1996) The Neoproterozoic-Lower Cambrian in Northern Govi-Altai, Western Mongolia: Regional Setting, Lithostratigraphy and Biostratigraphy. Geological Magazine, 133, 371-390. http://dx.doi.org/10.1017/S001675680000755X

[20] Voronin, Y.I., Voronova, I., Grigor’eva, L.G., Drozdova, N.A., Zhegallo, A.L., Zhuravlev, A.Y., Ragozina, A.L., Rozanov, A.Y., Sayutina, A.L., Sysoev, Y.A. and Fonin, V.D. (1982) The Precambrian-Cambrian Boundary in the Geosynclinal Areas (the Reference Section of Salaany-Gol, MPR). Nauka, Moscow, 150. (In Russian)

[21] Bezzubtsev, V.V. (1963) On the Precambrian-Cambrian Stratigraphy of the Dzabkhan River Basin. Proceeding Materials on the Geology of MPR, Ulaanbaatar, 29-42. (In Russian)

[22] Brasier, M.D., Dorjnamjaa, D. and Lindsay, J.F. (1996) The Neoproterozoic to Early Cambrian in Southwest Mongolia: An Introduction. Geological Magazine, 133, 365-369. http://dx.doi.org/10.1017/S0016756800007548

[23] Brasier, M., Green, O. and Shields, G. (1997) Ediacaran Sponge Spicule Clusters from Southwestern Mongolia and the Origins of the Cambrian Fauna. Geology, 25, 303-306. http://dx.doi.org/10.1130/0091-7613(1997)025<0303:ESSCFS>2.3.CO;2

[24] Lindsay, J.F., Brasier, M.D., Shields, G., Khomentovsky, V.V. and Bat-Ireedui, Y. (1996) Glacial Facies Associations in a Neoproterozoic Back-Arc Setting, Zavkhan Basin, Western Mongolia. Geological Magazine, 133, 391-402. http://dx.doi.org/10.1017/S0016756800007561

[25] Serezhnikova, E.A., Ragozina, A.L., Dorjnamjaa, D. and Zaitseva, L.V. (2014) Fossil Microbial Communities in Neoproterozoic Interglacial Rocks, Maikhanuul Formation, Zavkhan Basin, Western Mongolia. Precambrian Research, 245, 66-79. http://dx.doi.org/10.1016/j.precamres.2014.01.005

[26] Goldring, R. and Jensen, S. (1996) Trace Fossils and Biofabrics at the Precambrian-Cambrian Boundary Interval in Western Mongolia. Geological Magazine, 133, 403-415. http://dx.doi.org/10.1017/S0016756800007573 